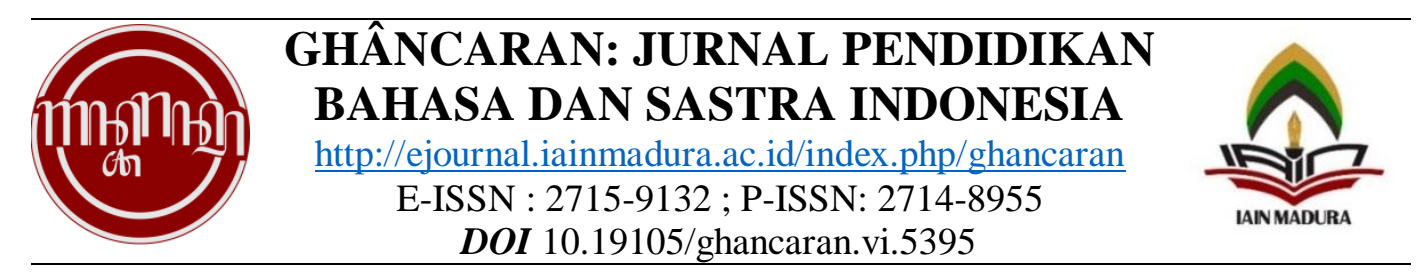

\title{
Sastra dan Sastrawan Jawa Timur di Era Pandemi: Tinjauan Respons Pembaca
}

\author{
Anas Ahmadi*, Darni ${ }^{\star *}$, Bambang Yulianto*** \\ * Bahasa dan Sastra Indonesia, Universitas Negeri Surabaya \\ ** Bahasa dan Sastra Jawa, Universitas Negeri Surabaya \\ ${ }^{* * *}$ Bahasa dan Sastra Indonesia, Universitas Negeri Surabaya \\ Alamat surel: anasahmadi@unesa.ac.id
}

\begin{abstract}
:
Keywords:

Literature;

Pandemi;

Reader

response.

This study aims to explore East Javanese literature and writers during the pandemic through the perspective of reader response. This study uses an interpretive qualitative approach. The informants in this study were professional literary readers and ordinary literary readers. as many as 84 respondents have responded to the Indonesian Literature Reader form in East Java from various categories with a distribution of 66.3 percent of undergraduate students; 18.8 percent of Lecturers; 8.4 percent of Teachers; 4.2 percent of General; Researchers and Doctoral students got the same result, namely 1.1 percent. Data collection techniques were carried out by means of interviews and questionnaires. The results of the study show the following. First, it represents the psychology of the author." 58.9 percent of respondents answered that the literary work represented the psychology of the author, 28.4 percent did not know and 12.6 percent did not. Second, the literary work represents the author's psychology, as many as 58.9 percent answered yes. While at least answering the literary work does not represent the psychology of the author, which is 12.6 percent. Third, the psychology understood by the reader, namely Personality Psychology (existential, behavioral, psychoanalytic, humanistic) with 28.4 percent answered yes, while at least 1.1 percent answered Masculinity Psychology and Mass Psychology. Indonesian writers in East Java tend to bring up Javanese human psychology in their literary works?" Of these questions, 52.6 percent of respondents answered that Indonesian writers in East Java tended to bring up Javanese human psychology in their literary works, as many as 42.1 percent answered maybe and 5.3 percent answered that Indonesian writers in East Java tended not to bring up Javanese human psychology in their literature. his literary works.
\end{abstract}

\begin{tabular}{ll}
\hline \hline \multicolumn{4}{l}{ Abstrak: } \\
\hline Kata Kunci: & Penelitian ini bertujuan untuk mengeksplorasi sastra dan \\
Sastra; & sastrawan Jawa Timur pada masa pandemi melalui \\
Sastra Jawa Timur; & perspektif respons pembaca. Penelitian ini menggunakan \\
Pandemi; & Pent
\end{tabular}


pendekatan kualitatif interpretatif. Informan dalam penelitian ini adalah pembaca sastra profesional dan pembaca sastra biasa. sebanyak 84 responden telah memberikan responsnya terhadap form Pembaca Sastra Indonesia di Jawa Timur dari berbagai kategori dengan distribusi sebanyak 66,3 persen dari Mahasiswa S1; 18,8 persen dari Dosen; 8,4 persen dari Guru; 4,2 persen dari Umum; Peneliti dan Mahasiswa S3 mendapat hasil yang sama yakni 1,1 persen. Teknik pengumpulan data dilakukan dengan cara wawancara dan pengangketan. Hasil penelitian menunjukkan sebagai berikut. Pertama, merepresentasikan psikologi sang pengarang" 58,9 persen responden menjawab karya sastra tersebut merepresentasikan psikologi sang pengarang, 28,4 persen tidak tahu dan sebanyak 12,6 persen tidak. Kedua, karya sastra tersebut merepresentasikan psikologi sang pengarang yakni sebanyak 58,9 persen menjawab ya. Sedangkan paling sedikit menjawab karya sastra tersebut tidak merepresentasikan psikologi sang pengarang yakni sebanyak 12,6 persen. Ketiga, psikologi yang dipahami oleh pembaca, yaknik Psikologi Kepribadian (eksistensial, behavioral, psikoanalisis, humanistik) yakni sebanyak 28,4 persen menjawab ya, sedangkan paling sedikit menjawab Psikologi Maskulinitas dan Psikologi Massa yakni sebanyak 1,1 persen. sastrawan Indonesia di Jawa Timur cenderung memunculkan psikologi manusia Jawa dalam karya sastranya?" Dari pertanyaan tersebut sebanyak 52,6 persen responden menjawab sastrawan Indonesia di Jawa Timur cenderung memunculkan psikologi manusia Jawa dalam karya sastranya, sebanyak 42,1 persen menjawab mungkin dan sebanyak 5,3 persen menjawab sastrawan Indonesia di Jawa Timur cenderung tidak memunculkan psikologi manusia Jawa dalam karya sastranya.

\begin{tabular}{ccc}
\hline \hline Terkirim: 25-08-2021 & ; Revisi: 23-09-2021 & ; Diterima: 25-11-2021 \\
\hline \hline OGhâncaran: Jurnal Pendidikan Bahasa dan Sastra Indonesia \\
Tadris Bahasa Indonesia \\
Institut Agama Islam Negeri Madura, Indonesia
\end{tabular}

\section{PENDAHULUAN}

Sastra dan sastrawan dunia dan termasuk juga Indonesia di dalamnya mengalami dampak dari resonansi pandemi covid yang menjalar di berbagai negara seluruh dunia. Tema sastra dalam konteks kritik mulai mengarah ke pandemi dan covid-19 (Bahtiar \& Ahmadi, 2020). Dunia kritik sastra mengarah pada wilayah penyakit dan pandemi menunjukkan bahwa sastra tdiak stagnan dalam perkembangannya. Sastra juga dituntut untuk di dalam. Tentunya, dalam hal ini dinamis dalam sastra berbeda dengan ilmu pengetahuan yang memang mau tidak mau harus mengikuti perkembangan zaman. Dalam konteks produksi sastra, kini sastra yang semula cetak (meski saat ini sudah mulai beberapa melirik platform digital) saat ini mengalami transformasi besar-besaran ke arah sastra digital (Siemens, \& Schreibman, 2013; 
Hoover, Culpeper, \& O'Halloran, (2016), baik dari karya ataupun publisher. Dalam konteks publisher, baik mayor, minor, ataupun independen, mereka yang selama ini lebih cenderung mengandalkan sastra cetak, mau tidak mau mengalihkan pandang ke platform digital. Mau tidak mau memang begitulah faktanya.

Dunia sedang menggelinding kearah digitalisasi. Internet saat ini benar-benar menjadi tumpuan utama. Karena itu, penerbit mulai menggunakan media online untuk menjual produk yang mereka terbitkan. Perubahan besar dalam sastra tersebut tidak lepas dari pandemi yang memang menyerang berbagai negara. Berkait dengan hal tersebut dalam artikel ini bertujuan untuk mengeksporasi respons pembaca mengenai sastra Indonesia di Jawa Timur. Selama ini, studi mengenai respons pembaca pernah dilakukan oleh peneliti berikut. Pertama, Whiteley \& Canning (2017) yang menawarkan studi alternatif respons pembaca untuk penelitian stilistika sastra dengan metode naturalistik. Kedua, Ahmadi, Darni, Murdiyanto, \& Hariyati (2019) yang meneliti konteks menulis keratif (sastra) yang dikaitkan dengan respons pembaca. Berdasarkan dua penelitian tersebut belum ditemukan peneliti yang menelaah sastra Indonesia di Jawa Timur melalui perspektif respons pembaca.

Teori yang digunakan dalam penelitian ini adalah respons pembaca yang mengacu pada pandangan Holland (...). Dipilihnya respons pembaca yang menggunakan pandgan Hollan dengan rasionalisasi berikut. Pertama, Holland adalah seorang psikolog yang mendalami sastra. Dengan begitu, pandangannya menyintesiskan psikologi dan sastra (Holland, 2006, 2009). kedua, Hollan sebagai seorang psikologi mengaitkan psikologi, sastra, dan pembaca. Dengan demikian, sintesis dari ketiganya diharapkan lebih komprehensif dalam memandang sastra sebagai karya pengarang yang tidak lepas dari psikologi pengarang, psikologi karya, dan psikologi pembaca.

Dalam pandangan Holland (1989) sastra tidak lepas dari respons pembaca. Seorang pembaca sastra memiliki pemahaman psikologis yang berbeda dengan pembaca yang lainnya. Namun, bisa juga sama/mirip dengan respons pembaca lainnya. Dalam hal ini, respons pembaca tersebut muncul sebab sang pembaca menggunakan psikenya dalam menafsirkan. McCormick (1985) menegaskan bahwa teori reader response-nya Holland leih mengarah pada subjectivitas pembaca. Hal tersebut disebabkan oleh faktor pembaca yang memiliki karakter psikologis yang berbeda-beda sebab mereka adalah sosok yang unik. Tyson (2018) menambahkan bahwa pandangan Holland tersebut memang disebabkan oleh pengaruh psikoanalisis 
yang digelutinya. Karena itu, setiap pembaca sastra memiliki motif dalam proses membaca.

Berkait dengan pandangan Holland (1989, 2006, 2009, 2017) mengenai respons pembaca, dalam konteks ini, teori tersebut diadaptasi oleh peneliti untuk menggali dan memahami tipe pembaca dalam sastra Indonesia di Jawa Timur. Pengadaptasian tersebut dilakukan untuk menemukenali tipe pembaca sastra Indonesia melalui perspektif psikologi. Pandangan Holland lebih difokuskan pada pemahaman pembaca sastra Indonesia mengenai sastra Indonesia di Jawa Timur.

Metode penelitian yang digunakan adalah kualitatif yang lebih mengedepankan paparan seara verbal dan interpretatif (Ahmadi, 2019, 2021; Creswell \& Creswell, 2020). Responden dalam penelitian ini adalah sebagai berikut. Pertama, responden yang profesional di bidang sastra dan sudah memiliki kelayakan di bidang sastra. Kedua, responden yang biasa, yakni responden yang memiliki minat bidang sastra, tetapi belum memiliki kelayakan di bidang sastra. Teknik pengumpulan data dilakukan dengan cara pengangketan dan wawancara. Pengangketan dilakukan secara daring menggunakan gform dan wawancara juga dilakukan secara daring dengan menggunakan platform zoom dan wa. Teknik analisis data menggunakan tahapan identifikasi hasil angket dan wawancara, klasifikasi, pemilihan data utama, dan paparan data final. Validitas data dilakukan dengan cara self-reviu dan peer-reviu. Dengan demikian, diharapkan tingkat validitas dalam penelitian ini lebih terjaga.

\section{ANALISIS DAN PEMBAHASAN}

Berdasarkan angket yang disebar oleh peneliti pada para responden berkait dengan sastra Indonesia di Jawa Timur dalam perspektif respons sang pembaca diperoleh data berikut. Dari google form diperoleh data sebanyak 84 responden telah memberikan responsnya terhadap form pembaca astra Indonesia di Jawa Timur dari berbagai kategori dengan distribusi sebanyak 66,3 persen dari Mahasiswa $\mathrm{S1} ; 18,8$ persen dari Dosen; 8,4 persen dari Guru; 4,2 persen dari Umum; Peneliti dan Mahasiswa S3 mendapat hasil yang sama yakni 1,1 persen. Tidak ada dari Mahasiswa S2, Siswa, Sastrawan, Kritikus, dan Penulis yang mengisi form. Semua responden berasal dari berbagai afiliasi. 

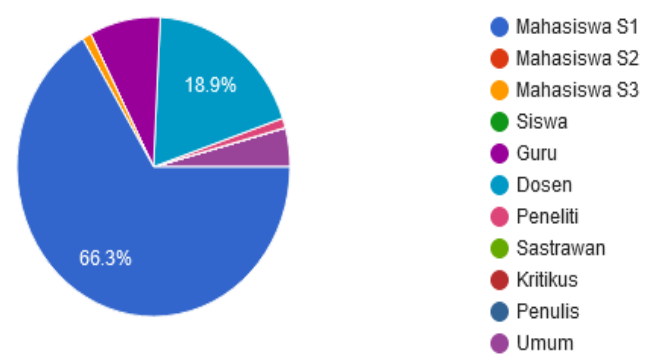

\section{Diagram 1: Kategori Responden}

Berdasarkan diagram tersebut, didapatkan hasil bahwa form Pembaca Sastra Indonesia di Jawa Timur paling banyak diisi oleh Mahasiswa S1 yakni sebanyak 66,3 persen. Sedangkan paling sedikit yakni Mahasiswa S3 dan Peneliti yang mendapat hasil sama yakni 1,1 persen. Pada pilihan kategori yang disediakan, tidak ada dari Mahasiswa S2, Siswa, Sastrawan, Kritikus, dan Penulis yang mengisi form. Dari beberapa pertanyaan yang terdapat pada form, didapatkan hasil sebagai berikut. Hasil pertanyaan "Apakah Anda suka mempelajari psikologi?"

Dari pertanyaan tersebut sebanyak 57,9 persen responden menjawab suka mempelajari psikologi, sebanyak 22,1 persen sangat suka dan sebanyak 20 persen menjawab biasa saja. Sedangkan tidak ada responden yang menjawab tidak suka.
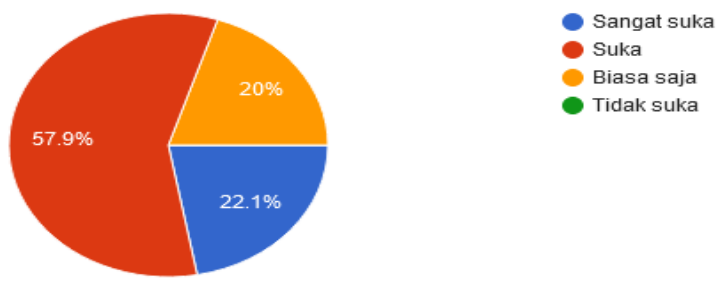

Tidak suka

Gambar 2: Menurut Anda, apakah karya sastra tersebut merepresentasikan psikologi sang pengarang"

Berdasarkan diagram yang berkait dengan "Menurut Anda, apakah karya sastra tersebut merepresentasikan psikologi sang pengarang" diperoleh data 58,9 persen responden menjawab karya sastra tersebut merepresentasikan psikologi sang pengarang, sebanyak 28,4 persen tidak tahu dan sebanyak 12,6 persen menjawab karya sastra tersebut tidak merepresentasikan psikologi sang pengarang. 


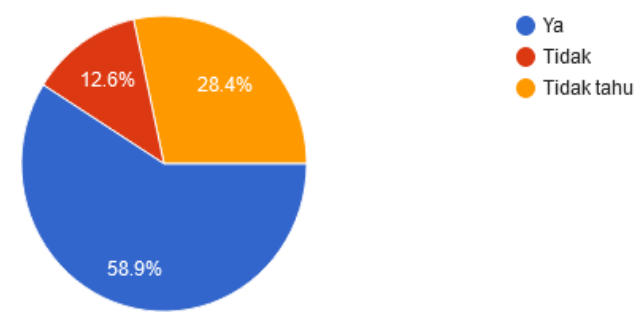

Diagram 3: Respons "Menurut Anda, apakah karya sastra tersebut merepresentasikan psikologi sang pengarang"

Berdasarkan diagram tersebut, didapatkan hasil bahwa responden paling banyak menjawab karya sastra tersebut merepresentasikan psikologi sang pengarang yakni sebanyak 58,9 persen. Sedangkan paling sedikit menjawab karya sastra tersebut tidak merepresentasikan psikologi sang pengarang yakni sebanyak 12,6 persen Hasil pertanyaan "Dari beberapa karya sastra Indonesia yang ditulis oleh Sastrawan Jawa Timur, psikologi apakah yang paling dominan menurut Anda?"

Dari pertanyaan tersebut sebanyak 28,4 persen responden menjawab Psikologi Kepribadian (eksistensial, behavioral, psikoanalisis, humanistik); sebanyak 20 persen menjawab Psikologi Antropologi; sebanyak 14,7 persen menjawab Psikologi Agama; sebanyak 9,5 persen menjawab Psikologi Feminitas; sebanyak 8,4 persen menjawab Psikologi Multikulturalisme; sebanyak 7,5 persen menjawab Psikologi Lingkungan; sebanyak 5,3 persen menjawab Psikologi Lokal; sebanyak 1,1 persen menjawab Psikologi Maskulinitas; sebanyak 1,1 persen menjawab Psikologi Massa; tidak ada responden yang menjawab Psikologi Geografi pada pilihan form; dan sebanyak 4,4 persen menjawab lainnya dengan jawaban serupa yakni tidak tau.
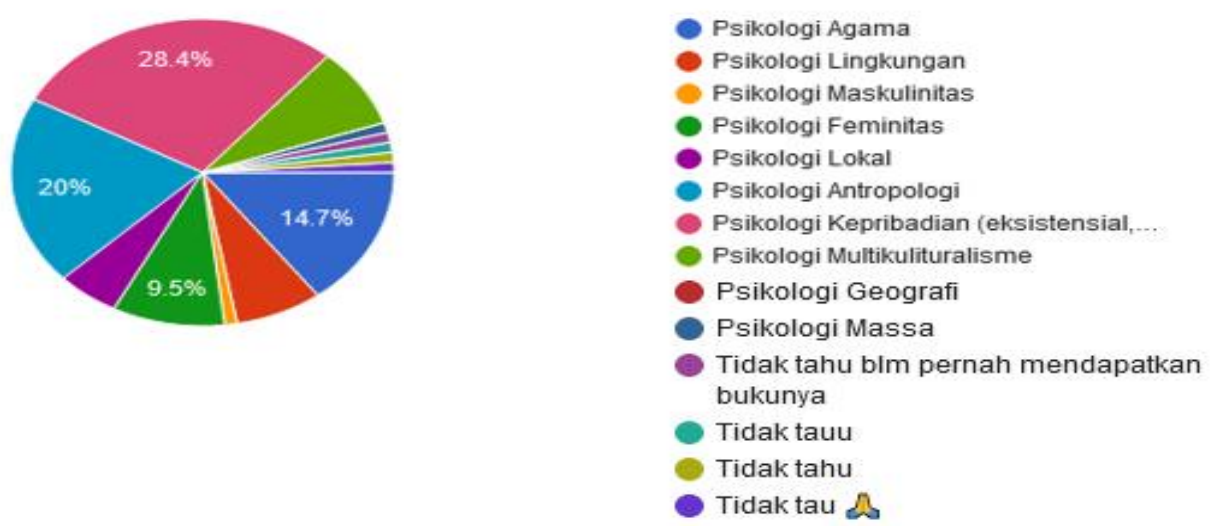

Diagram 4: Respons "Dari beberapa karya sastra Indonesia yang ditulis oleh Sastrawan Jawa Timur, psikologi apakah yang paling dominan menurut Anda?" 
Berdasarkan diagram tersebut, didapatkan hasil bahwa responden paling banyak menjawab Psikologi Kepribadian (eksistensial, behavioral, psikoanalisis, humanistik) yakni sebanyak 28,4 persen. Sedangkan paling sedikit menjawab Psikologi Maskulinitas dan Psikologi Massa yakni sebanyak 1,1 persen. Pada pilihan kategori yang disediakan, tidak ada yang menjawab Psikologi Geografi.

Hasil pertanyaan "Apakah sastrawan Indonesia di Jawa Timur cenderung memunculkan psikologi manusia Jawa dalam karya sastranya?"

Dari pertanyaan tersebut sebanyak 52,6 persen responden menjawab sastrawan Indonesia di Jawa Timur cenderung memunculkan psikologi manusia Jawa dalam karya sastranya, sebanyak 42,1 persen menjawab mungkin dan sebanyak 5,3 persen menjawab sastrawan Indonesia di Jawa Timur cenderung tidak memunculkan psikologi manusia Jawa dalam karya sastranya.

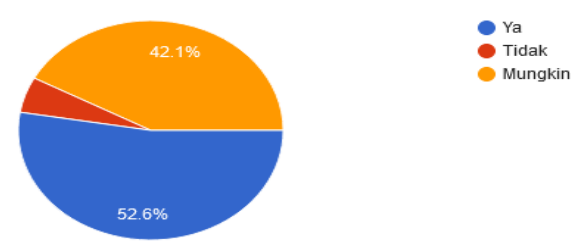

Diagram 5: Respons “Apakah sastrawan Indonesia di Jawa Timur cenderung memunculkan psikologi manusia Jawa dalam karya sastranya?

Berdasarkan diagram tersebut, didapatkan hasil bahwa responden paling banyak menjawab sastrawan Indonesia di Jawa Timur cenderung memunculkan psikologi manusia Jawa dalam karya sastranya yakni sebanyak 52,6 persen. Sedangkan paling sedikit sastrawan Indonesia di Jawa Timur cenderung tidak memunculkan psikologi manusia Jawa dalam karya sastranya yakni sebanyak 5,3 persen.

\section{Simpulan}

Berdasarkan hasil paparan di muka disimpulkan sebagai berikut. Pertama, untuk pertanyaan 1, Menurut Anda, apakah karya sastra tersebut merepresentasikan psikologi sang pengarang" diperoleh jawaban sebanyak 58,9 persen responden menjawab karya sastra tersebut merepresentasikan psikologi sang pengarang, sebanyak 28,4 persen tidak tahu dan sebanyak 12,6 persen menjawab karya sastra tersebut tidak merepresentasikan psikologi sang pengarang. Kedua, untuk pertanyaan 2, Menurut Anda, apakah karya sastra tersebut merepresentasikan psikologi sang pengarang. Dari pertanyaan tersebut sebanyak 58,9 persen responden menjawab karya sastra tersebut merepresentasikan psikologi sang pengarang, sebanyak 28,4 
persen tidak tahu dan sebanyak 12,6 persen menjawab karya sastra tersebut tidak merepresentasikan psikologi sang pengarang. Ketiga, untuk pertanyaan 3, "Dari beberapa karya sastra Indonesia yang ditulis oleh Sastrawan Jawa Timur, psikologi apakah yang paling dominan menurut Anda?". Dari pertanyaan tersebut sebanyak 28,4 persen responden menjawab Psikologi Kepribadian (eksistensial, behavioral, psikoanalisis, humanistik); sebanyak 20 persen menjawab Psikologi Antropologi; sebanyak 14,7 persen menjawab Psikologi Agama; sebanyak 9,5 persen menjawab Psikologi Feminitas; sebanyak 8,4 persen menjawab Psikologi Multikulturalisme; sebanyak 7,5 persen menjawab Psikologi Lingkungan; sebanyak 5,3 persen menjawab Psikologi Lokal; sebanyak 1,1 persen menjawab Psikologi Maskulinitas; sebanyak 1,1 persen menjawab Psikologi Massa; tidak ada responden yang menjawab Psikologi Geografi pada pilihan form; dan sebanyak 4,4 persen menjawab lainnya dengan jawaban serupa yakni tidak tau. Keempat, untuk pertanyaan 4, Apakah sastrawan Indonesia di Jawa Timur cenderung memunculkan psikologi manusia Jawa dalam karya sastranya?" Dari pertanyaan tersebut sebanyak 52,6 persen responden menjawab sastrawan Indonesia di Jawa Timur cenderung memunculkan psikologi manusia Jawa dalam karya sastranya, sebanyak 42,1 persen menjawab mungkin dan sebanyak 5,3 persen menjawab sastrawan Indonesia di Jawa Timur cenderung tidak memunculkan psikologi manusia Jawa dalam karya sastranya.

\section{DAFTAR PUSTAKA}

Ahmadi, A. (2019). Metode penelitian sastra. Gresik: Graniti.

Ahmadi, A. (2021). The traces of oppression and trauma to ethnic minorities in Indonesia who experienced rape on the 12 May 1998 tragedy: A review of literature. Journal of Ethnic and Cultural Studies, 8(2), 126-144.

Ahmadi, A., Darni, Murdiyanto, \& Hariyati, N. R. (2019). Reader's response and learning writing psychological perspective. Journal of Arts and Humanities, 8(9), 11-15. https://www.theartsjournal.org/index.php/site/article/view/1710

Bahtiar, A. \& Ahmadi, A. (2020). Relasi kuasa dalam dua novel Indonesia modern berlatar wabah. Kelasa, 15 (2), 150-169, https://doi.org/10.26499/kelasa.v15i2.126

Creswell, J. W., \& Creswell, J. D. (2020). Research design: Qualitative, quantitative, and mixed methods approaches. New York: Sage.

Holland, N. N. (2017). The nature of literary response: Five readers reading. New York: Routledge.

Holland, N. N. (1989). The dynamics of literary response. New York: Columbia University Press.

Holland, N. N. (2006). Holland's guide to psychoanalytic psychology and literature-andpsychology. New York: Oxford University Press.

Holland, N. N. (2009). Literature and the brain. Gainesville, Fla: PsyArt Foundation.

Hoover, D. L., Culpeper, J., \& O'Halloran, K. (2016). Digital literary studies: Corpus approaches to poetry, prose, and drama. New York: Palgrave. 
Tyson, L. (2018). Critical theory today: A user-friendly guide. London: Routledge.

McCormick, K. (1985). Theory in the Reader: Bleich, Holland, and beyond. College English, 47(8), 836-850. doi:10.2307/376620

Siemens, R. G., \& Schreibman, S. (2013). A companion to digital literary studies. Hoboken, N.J: Wiley-Blackwell.

Whiteley, S., \& Canning, P. (2017). Reader response research in stylistics. Language and Literature, 26(2), 71-87. https://doi.org/10.1177/0963947017704724 